\title{
The Effects of Instructional, Transformation and Distributed Leadership on Students' Academic Outcomes: A Meta -Analysis
}

\author{
Yousef Ogla Almarshad ${ }^{1, *}$ \\ ${ }^{1}$ College of Education, Jouf University, Saudi Arabia \\ *Correspondence: College of Education, Jouf University, Saudi Arabia. E-mail: \\ dralmarshad@gmail.com
}

Received: November 3, 2016 Accepted: December 17, 2016 Published: May 23, 2017

doi:10.5296/ije.v9i2.10263 URL: https://doi.org/10.5296/ije.v9i2.10263

\begin{abstract}
This paper reviewed the effects of educational leadership on students' academic outcomes during the past decade. 14 studies were found and included with the computation of 16 effect size statistics. This research evaluated the effect of three different types of leadership, instructional, transformational and distributed, on students' academic achievement. The study found no discernable differences with respect to the type of leadership on students' academic outcomes.

Discernable leadership was found to be the most influential leadership style on students' academic achievement. This finding confirms earlier arguments suggesting that if leaders are more engaged in the business of teaching and learning of their students, the academic performance of schools pupils become better. In light of earlier reviews of leadership effects on students' outcomes, this study shows that the influence of leadership on academic measures differs from its effects on non-academic outcomes including social, psychological and political characteristics.
\end{abstract}

Keywords: educational leadership, students achievement, students outcomes, instructional leadership, transformational leadership and distributed leadership 


\section{Introduction}

The investigation of the relationship between educational leadership and students' outcomes has acquired unprecedented attention among scholars, educators and policy makers in the past two decades on a global scale. More than six systematic and empirical analyses have been conducted to estimate the direct and indirect effects of different leadership styles on students' achievements (Bell, Bolam \& Cubillo, 2003; Chin, 2007; Leithwood \& Sun, 2012; Leithwood, Day, Sammons, Harris \& Hopkins, 2006; Robinson, Lloyd \& Rowe, 2008 and Witziers, Bosker \& Krüger, 2003).

The increasing interest in educational leadership stems from the popularized belief that successful leadership produces better school outcomes (Robinson, Lloyd \& Rowe, 2008; Marzano, Waters \& McNulty, 2005). Case studies, as well as qualitative research have presented many stories of falling schools that with the help of the right kind of leadership transformed into successful educational institutions (Valentine \& Prater, 2011; Menon, 2015). Policy makers around the world have increasingly emphasized the role of successful educational leaders in reducing achievement gaps among various populations. Educational ministries, as well as departments across the industrial and developing worlds have heavily invested in the creation of educational leadership programs with the realization that leadership determines a significant portion of the variation in a range of students' outcomes (Mundy \& Verger, 2015).

Despite the positive association narrative one gets from the qualitative research, the empirical results linking educational leadership and students' outcomes are inconclusive at best (Witziers, Bosker, \& Krüger (2003); Leithwood \& Sun (2012) ;Robinson , Lloyd \& Rowe (2008). In their meta-analysis of published 27 studies, Robinson et al (2008) reported that leadership had a mean effect size ranging from 0.1 to 0.4 depending on the style of leadership (weak to moderate effects). In their meta-analysis of unpublished literature, Leithwood and Sun (2012) found that the effect of leadership on aggregate students' achievement was 0.09 indicating very little to no effect on students' outcomes. More recently, Karadag et al (2015) conducted a meta-analysis of published and unpublished research concluding that educational leadership had an average effect of 0.34 on students' achievement indicating a moderate association. This finding confirms earlier findings by Marzano (2003) who reported an average effect of about 0.4 indicating a positive relationship between leadership and students' outcomes/achievement. Those findings contradict an earlier study by Witziers that reported an effect size of about 0.02 indicating no association between leadership and students' outcomes. This confusion of empirical findings leads the interested researcher or policy maker with little to know clue regarding the relationship between educational leadership and students' outcomes.

The drastic differences in the findings of the quantitative scholarship on the effect of leadership on students' achievement is likely due to different methodological specifications. First, many studies used non-academic students' outcome measures, social, psychological and non-academic attributes, as the dependent variable. This specification is likely to increase the magnitude of leadership effects on students' non-academic outcomes given the larger role 
school administrators play in setting the mission, vision and management of schools rather than directly interact with students' teaching or learning on a daily basis like teachers. Second, many studies only included published research, which dramatically decreased the number of available investigations. The inclusion of unpublished literature is likely to increase the sample of available studies thereby adding more robustness to the estimates of leadership effects on students' outcomes. Third, authors have often selected certain types of leadership (transformational, instructional, distributed or other) generating different estimates. Fourth, authors have used different instruments to measure leadership, as well as students' achievement leading to varying empirical findings.

The inconsistencies in the empirical research poses significant challenges to policy makers, as well as professional educators. First, many findings allude to the weak indirect effect of leadership on students' outcomes contradicting the cemented belief among education policy makers' circles concluding a moderate to strong positive association between the two constructs (Shatzer, Caldarella, Hallam \& Brown, 2013; Alia, 2015). More importantly, the drastic variation of the empirical findings with respect to the type of leadership (instructional, transformational, distributed or other) effect on students' achievement hinders policy change, as well as school efforts in organizational change due to the confusion surrounding what type best serves schools. The absence of concrete knowledge on the effect of leadership on students' achievement impedes the continuous process of schools' improvement. Finding the effect of various leadership styles on students' achievement aids policy makers and education professionals with the necessary knowledge to proceed with meaningful changes that bring improved students' performance.

The purpose of this study is to address the gap in existing empirical investigations of the effect of leadership on students' achievement. This research expands on previous efforts of quantitatively estimating the effects of leadership on students' outcomes by considering previously neglected leadership styles; namely distributed leadership. Karadag's et al (2015) review only included 2 studies capturing the effect of distributed leadership while this study included 4. The research is also specific to the analysis of educational leadership effects on academic outcomes excluding all other non-academic measures. Finally, the study marks one of the first systematic analyses of the effects of three types of leadership, instructional, transformational and distributed) on students' academic outcomes in the past decade. Non-academic writing and policy making efforts have been intensified in the past decade trying to link different types of leadership to students' achievement, therefore the need for an empirically based systematic investigation of leadership effects on students outcomes is warranted.

The first section of the paper will present a brief introduction to three distinct types of educational leadership, instructional, transformational and distributed. Second, a brief discussion on the methods, studies and analytical strategies utilized in this research is outlined. The overarching methodology of the research is meta-analysis. 14 published and unpublished studies between 2006-2015 were used for the computation of effect sizes. All studies reported correlational statistics that allowed the computation of the correlation coefficient as the effect size metric chosen for the study. 
Educational leadership has a weak to moderate effect on students' academic outcomes, however measured. Instructional, transformation and distributed leadership styles had an average effect ranging between $\mathrm{ES}=0.26-0.28$ on students' academic outcomes. This indicates that school leaders may not play the most significant role in determining students' academic performance. Nevertheless, this evidence is indicative of the main role of leaders in creating conducive environments for teaching and learning, which constitute the most robust predictor of students' achievement. One of the most noteworthy results of the analysis is that distributed leadership had a stronger effect on students' academic achievement compared to instructional or transformational leadership. This dynamic is likely due to the more involvement of school leaders with the business of teaching and learning since distributed leadership entails the sharing of leadership responsibilities across all leadership ranks in the school administration.

\section{Instructional Leadership}

Instructional leadership suggests that setting clear objectives, a learning environment free from all types of noise, high expectations from teachers and smart goals for schools' outcomes generate a success story for failing schools (Neumerski, 2013; Zepeda, 2013). Instructional leadership has developed in poor urban schools in the United States where strong educational leaders have turned around deteriorating schools into narratives of educational achievement. Instructional leadership has shaped the evolution of educational leadership as a field and practice on a global scale (Lee, Walker \& Ling Chui, 2012).

Early delineations of the theory assumed that schools' principals represent the main figures of leadership in educational institutions. Therefore, the measurement of theory has overwhelmingly focused on the attributes, characteristics and practices of principals marginalizing other key administrators that play pivotal roles in setting schools objectives, learning settings and outcomes (Horng \& Loeb, 2010; Bauer,2013). This trend has contributed to the aggrandizement of the role of the principal as the most important actor in making or breaking a school. Recent applications of the theory have been more inclusive integrating the role of other school administrators as significant leaders within their schools. This shift has largely contributed to the rise of collective or shared leadership.

A recent analysis of the effect of instructional leadership on students' achievement has been investigated extensively has concluded that instructional leadership has a weak positive impact on students' academic achievement. Other studies have found instructional leadership to have stronger effects, especially when one compares it to other models of leadership, shared or transformational ((Bell, Bolam \& Cubillo, 2003; Chin, 2007; Leithwood \& Sun, 2012; Leithwood, Day, Sammons, Harris \& Hopkins, 2006; Robinson, Lloyd \& Rowe, 2008 and Witziers, Bosker \& Krüger, 2003).). The evidence suggests that the effect of instructional leadership on students' outcomes is unclear and inconclusive. 


\section{Distributed Leadership}

Distributed leadership has originated within the field of psychology suggesting that leadership should not be viewed as a characteristic of a single individual rather as a group attribute. Distributed leadership has gained popularity among educational leadership scholars and practitioners since individualized models of leadership have been shown to be unrealistic and difficult to attain (Spillane, 2012). Distributed leadership posits that the shared patterns of communication, action, learning and administration among school leaders and teachers generates an effect on schools', as well as students' outcomes. Distributed leadership has been embraced with unprecedented enthusiasm among educational leadership experts (Harris, 2013; Kempster, Higgs \& Wuerz, 2014). The common belief that shared functions among everyone working at the school matters in determining students' outcomes has gained importance given its straightforward nature.

One of the most recent reviews on the effect of distributed leadership on students' achievement concluded that distributed leadership has a greater effect on students' outcomes compared to traditional to-down approaches (Karadağ, Bektaş, Çoğaltay \& Yalçın. 2015). Nevertheless, the empirical evaluation of distributed leadership models is still in its infancy with few published articles investigating its effects on students' academic abilities.

\section{Transformational Leadership}

Burns' analysis of organizations' leaders has cemented the idea that leaders can energize, motivate, inspire and change their subordinates work morale, purpose, mission and vision generating a positive impact on the performance of the organization. Those connections mark significant departures from earlier traditional models of leadership that emphasized hierarchical and authoritative relationships between leaders and followers (Bass \& Riggio, 2006; Bass, 1999). The increasingly ability of leaders to connect with employees is thought to raise the levels of organizational communication, collaboration and performance transforming the work nature in the organization making it capable of achieving its goals and overcoming its challenges.

Bass has constructed survey instruments to measure the complex constructs of transformational leadership and investigate its effects on a host of organizational outcomes. Many educational leadership scholars have utilized such instruments in their investigations of the effect of leadership on students' outcomes. Such studies produced varying effects of transformational leadership on students' achievement with many arguing that transformational leadership has a weaker effect on students' outcomes compared to instructional or distributed leadership (Menon, 2015).

\section{Method}

This study utilizes meta-analysis as the research strategy to estimate the effect of instructional, distributed and transformational leadership on students' academic achievement. 
Meta-analysis enables researchers to aggregate quantitative studies between two variables to generate an average effect of one variable on the other. This effect shows the magnitude, as well as the direction of the relationship between the two constructs. Meta-analysis permit researchers to convert different statistical measures, correlations, regression coefficients, path confidents, t-statistics and others, into a common metric known as the effect size. There are many effect size measures, $\mathrm{z}$ scores, correlations, means and many others. Nevertheless, effect size statistics convey the same information, a measure of the magnitude and direction of the effect of one variable on another (Lipsey \& Wilson, 2001).

Meta-analysis possesses several strengths over other techniques. First, compared to a traditional literature review, meta-analysis generates a quantitate measure that captures the average effect of one variable on another. Second, meta-analysis requires researchers to carefully survey the relevant literature for studies to be included in the analysis. Third, meta-analysis can integrate findings produced by varying statistical models in a unified framework that is easily interpretive (Hedges \& Olkin, 2014).

\section{Selection of Studies and Analytical Techniques}

The study began with a comprehensive search for English language published, as well as unpublished studies investigating the direct effects of educational leadership on students' academic outcomes. This resulted in the elimination of studies that linked educational leadership with students' non-academic outcomes. Further, the synthesis included all studies that measured the impact of educational leadership, however specified, and its impact on students' achievement. The study only focused on principals, as well as key school administrators thus excluding the teaching leadership side of the narrative.

The search started with navigating electronic databases using a combination of distinct keywords revolving around the link between leadership and students' outcomes (effect of leaders, principals, school administrators on students' achievement, test scores or academic performance). Second, a more detailed search was conducted on relevant journals in education, leadership and management. Finally, the researcher explored reference lists of meta-analyses previously conducted on the topic, publications in international journals and other types of publications, book chapters, reports and relevant documents in order to solicit candidate studies for the research.

The search excluded any study that was conducted prior to 2006 and did not report correlational statistics on the direct relationship between educational leadership and students' academic outcomes. This limited the number of available studies to the research to only 14 with two reporting more than an effect statistic on the relationship linking leadership to students' academic outcomes. Table 1 displays the studies included in this research. The vast majority of studies included were conducted in the United States (12 out of 14) and one study was conducted in the Netherlands and another in Indonesia.

Nine studies investigated the relationship between leadership and students' outcomes in elementary schools while 7 conducted their analyses using samples from middle, as well as 


\section{MInstitute Macrothink $^{\text {Int }}$}

high schools. Few studies included both primary, as well as secondary schools. Six effects were retrieved linking transformation, as well as instructional leadership styles to students' academic outcomes. Four empirical studies linked distributed leadership (more than 2, the number of studies found in the most recent meta-analysis in 2015) to students' academic achievement.

Note that all included studies evaluated the effect of leadership on academic outcomes usually measured in reading, mathematics, language test scores. Comparing the number of studies, in light of the covered time period, notes to the comprehensive nature of the thorohgh investigation of the study. Previous research conducted by Robinson et al (2008) yielded 27 studies between 1978 and 2006 while including non-academic outcomes enlarging the pool of studies included. Further, in line with the literature criticism of excluding unpublished studies, mainly dissertations or conference papers, this study included all studies, published or unpublished that reported measures of correlation, regression coefficients or path coefficients linking leadership to students' outcome s directly.

Since one of the criteria for inclusion in the study was to possess correlational statistics linking leadership to students' outcomes directly, it was possible to estimate 16 effect sizes for all 14 studies, two studies assessed more than one leadership style. A pre-processing worksheet including characteristics of studies: type of school, leadership theory, measurement tools, students' outcomes included, sample size, country and relevant statistics was prepared for the analysis.

Statistical measures reported by the studies were converted into effect size metrics, correlation coefficients. The choice of this effect size metric is informed by its ease of computation given the original statistics reported in the included studies, as well as its simple interpretability. The last column of table 1 lists effect sizes, correlations, for the 14 studies, if studies reported more than a statistic the average effect size is obtained and presented in the table.

Table 1. The Relationship between Leadership and Students' Outcomes

\begin{tabular}{|c|c|c|c|c|c|c|c|}
\hline Reference & Schools & Leadership Theory & $\begin{array}{l}\text { Leadership } \\
\text { Measure }\end{array}$ & $\begin{array}{l}\text { Students' } \\
\text { Outcome Measure }\end{array}$ & $\mathrm{n}$ & Country & $\begin{array}{l}\text { Effect } \\
\text { Size } \\
\text { (r) }\end{array}$ \\
\hline $\begin{array}{l}\text { Quinn, R, } \\
\text { (2011) }\end{array}$ & $\begin{array}{l}\text { Elementary } \\
\text { Schools }\end{array}$ & $\begin{array}{l}\text { Instructional } \\
\text { Leadership }\end{array}$ & $\begin{array}{l}\text { Instructional } \\
\text { Activity } \\
\text { Questionnaire } \\
\text { (IAQ) }\end{array}$ & $\begin{array}{l}\text { Reading/Languag } \\
\text { e Arts CRTC } \\
\text { Scores }\end{array}$ & 66 & USA & 0.06 \\
\hline Alia, (2015) & $\begin{array}{l}\text { Elementary } \\
\text { Schools }\end{array}$ & $\begin{array}{l}\text { Instructional } \\
\text { Leadership }\end{array}$ & $\begin{array}{l}\text { Leadership } \\
\text { Behavior } \\
\text { Description } \\
\text { Questionnaire } \\
\text { (LPDQ) }\end{array}$ & $\begin{array}{l}\text { STAR } \\
\text { Mathematics } \\
\text { Scores }\end{array}$ & 130 & USA & 0.33 \\
\hline
\end{tabular}




\begin{tabular}{|c|c|c|c|c|c|c|c|}
\hline $\begin{array}{l}\text { Seashore } \\
\text { Louis, } \\
\text { Dretzke \& } \\
\text { Wahlstrom, } \\
(2010)\end{array}$ & $\begin{array}{l}\text { Secondary } \\
\text { school }\end{array}$ & Distributed Leadership & $\begin{array}{l}\text { Survey of } \\
\text { teachers' } \\
\text { perceptions } \\
\text { of Distributed } \\
\text { Leadership }\end{array}$ & Math Proficiency & 8391 & USA & 0.17 \\
\hline $\begin{array}{l}\text { Seashore } \\
\text { Louis, } \\
\text { Dretzke \& } \\
\text { Wahlstrom, } \\
(2010)\end{array}$ & $\begin{array}{l}\text { Secondary } \\
\text { school in } \\
\text { Secondary } \\
\text { schools }\end{array}$ & $\begin{array}{l}\text { Instructional } \\
\text { Leadership }\end{array}$ & $\begin{array}{l}\text { Survey of } \\
\text { teachers' } \\
\text { perception of } \\
\text { Instructional } \\
\text { Leadership }\end{array}$ & Math Proficiency & 8391 & USA & -0.07 \\
\hline $\begin{array}{l}\text { Supriadi \& } \\
\text { Yusof, (2015) }\end{array}$ & $\begin{array}{l}\text { Primary } \\
\text { schools }\end{array}$ & $\begin{array}{l}\text { Instructional } \\
\text { Leadership }\end{array}$ & $\begin{array}{l}\text { Questionnaire } \\
\text { of } 32 \text { items } \\
\text { borrowed } \\
\text { from } \\
\text { Hallinger } \\
(1987)\end{array}$ & $\begin{array}{l}\text { Achievement } \\
\text { scale }\end{array}$ & 157 & Indonesia & 0.49 \\
\hline $\begin{array}{l}\text { Herndon, } \\
(2007)\end{array}$ & $\begin{array}{l}\text { Elementary } \\
\text { Schools }\end{array}$ & $\begin{array}{l}\text { Transformational } \\
\text { Leadership }\end{array}$ & $\begin{array}{l}\text { Servant } \\
\text { Leadership } \\
\text { Assessment }\end{array}$ & $\begin{array}{l}\text { MAP } \\
\text { Mathematics } \\
\text { Scores }\end{array}$ & 667 & USA & 0.25 \\
\hline $\begin{array}{l}\text { Shatzer, et al, } \\
\text { (2013) }\end{array}$ & $\begin{array}{l}\text { Elementary } \\
\text { schools }\end{array}$ & $\begin{array}{l}\text { Instructional } \\
\text { Leadership }\end{array}$ & $\begin{array}{l}\text { Principal } \\
\text { Instructional } \\
\text { Management } \\
\text { Rating Scale } \\
\text { (PIMRS) }\end{array}$ & $\begin{array}{l}\text { Criterion } \\
\text { Reference Test } \\
(\mathrm{CRT}) \text {. } \\
\text { Statewide test } \\
\text { scores. }\end{array}$ & 37 & USA & 0.81 \\
\hline $\begin{array}{l}\text { Shatzer, et al, } \\
\text { (2013) }\end{array}$ & $\begin{array}{l}\text { Elementary } \\
\text { schools }\end{array}$ & $\begin{array}{l}\text { Transformational } \\
\text { Leadership }\end{array}$ & $\begin{array}{l}\text { Multifactor } \\
\text { Leadership } \\
\text { Questionnaire } \\
\text { (MLQ) }\end{array}$ & $\begin{array}{l}\text { Criterion } \\
\text { Reference Test } \\
(\mathrm{CRT}) \text {. } \\
\text { Statewide test } \\
\text { scores. }\end{array}$ & 37 & USA & 0.59 \\
\hline $\begin{array}{l}\text { Goddard, et } \\
\text { al, (2010) }\end{array}$ & $\begin{array}{l}\text { Elementary } \\
\text { Schools }\end{array}$ & Distributed Leadership & $\begin{array}{l}\text { Authors } \\
\text { developed } \\
\text { three } \\
\text { measures } \\
\text { using } \\
\text { teachers' } \\
\text { reports }\end{array}$ & Math scores & 96 & USA & 0.23 \\
\hline
\end{tabular}




\begin{tabular}{|c|c|c|c|c|c|c|c|}
\hline $\begin{array}{l}\text { Leithwood \& } \\
\text { Mascall, } \\
\text { (2008) }\end{array}$ & $\begin{array}{l}\text { Elementary } \\
\text { and } \\
\text { Secondary } \\
\text { schools }\end{array}$ & Distributed Leadership & $\begin{array}{l}\text { Leithwood's } \\
\text { Questionnaire }\end{array}$ & $\begin{array}{l}\text { Percentage of } \\
\text { students meeting } \\
\text { the proficiency } \\
\text { levels in language } \\
\text { and mathematics } \\
\text { state-wide tests }\end{array}$ & 2570 & USA & 0.35 \\
\hline $\begin{array}{l}\text { Moolenaar \& } \\
\text { Daly, (2012) }\end{array}$ & $\begin{array}{l}\text { Elementary } \\
\text { schools }\end{array}$ & Distributed Leadership & $\begin{array}{l}\text { Collective } \\
\text { Efficacy } \\
\text { scales from } \\
\text { teachers' } \\
\text { reports }\end{array}$ & $\begin{array}{l}\text { Math and } \\
\text { language ability } \\
\text { tests }\end{array}$ & & $\begin{array}{l}\text { Netherlan } \\
\text { ds }\end{array}$ & 0.41 \\
\hline Ko, (2015) & Preschools & $\begin{array}{l}\text { Transformational } \\
\text { Leadership }\end{array}$ & $\begin{array}{l}\text { Transformati } \\
\text { onal School } \\
\text { Leadership } \\
\text { Survey }\end{array}$ & $\begin{array}{l}\text { Young } \\
\text { Mathematics and } \\
\text { Literacy } \\
\text { Achievement } \\
\text { Scores }\end{array}$ & 194 & USA & 0.46 \\
\hline $\begin{array}{l}\text { Hardman, } \\
(2011)\end{array}$ & $\begin{array}{l}\text { Elementary, } \\
\text { Middle and } \\
\text { High Schools }\end{array}$ & $\begin{array}{l}\text { Transformational } \\
\text { Leadership }\end{array}$ & $\begin{array}{l}\text { Multifactor } \\
\text { Leadership } \\
\text { Questionnaire } \\
\text { (MLQ) }\end{array}$ & $\begin{array}{l}\text { Florida } \\
\text { Comprehensive } \\
\text { Assessment }\end{array}$ & 143 & USA & 0.17 \\
\hline Chen, (2014) & $\begin{array}{l}\text { Middle and } \\
\text { High Schools }\end{array}$ & $\begin{array}{l}\text { Transformational } \\
\text { Leadership }\end{array}$ & $\begin{array}{l}\text { Leadership } \\
\text { Practices } \\
\text { Index }\end{array}$ & $\begin{array}{l}\text { Academic } \\
\text { Performance } \\
\text { Index }\end{array}$ & 138 & USA & -0.05 \\
\hline $\begin{array}{l}\text { Valentine \& } \\
\text { Prater, (2011) }\end{array}$ & High Schools & $\begin{array}{l}\text { Instructional } \\
\text { Leadership }\end{array}$ & $\begin{array}{l}\text { Audit of } \\
\text { Principal } \\
\text { Effectiveness }\end{array}$ & MAP Scores & 131 & USA & 0.04 \\
\hline $\begin{array}{l}\text { Valentine \& } \\
\text { Prater, (2011) }\end{array}$ & High Schools & $\begin{array}{l}\text { Transformational } \\
\text { Leadership }\end{array}$ & $\begin{array}{l}\text { Principal } \\
\text { Leadership } \\
\text { Questionnaire } \\
\text { s }\end{array}$ & MAP Scores & 131 & USA & 0.17 \\
\hline
\end{tabular}

\section{Findings}

Figure 1 shows the mean effect size estimates for the impact of instructional leadership 0.27 , transformational leadership 0.26 and distributed leadership 0.28 on students' academic outcomes. First, note the similarity of the effect of the three different types of leadership on students' academic outcomes. Second, notice that distributed leadership had the strongest 
effect on students' academic performance compared to the other two. Nevertheless, the practical difference in the impact of different types of leadership on students' academic outcomes seems to be non-existent.

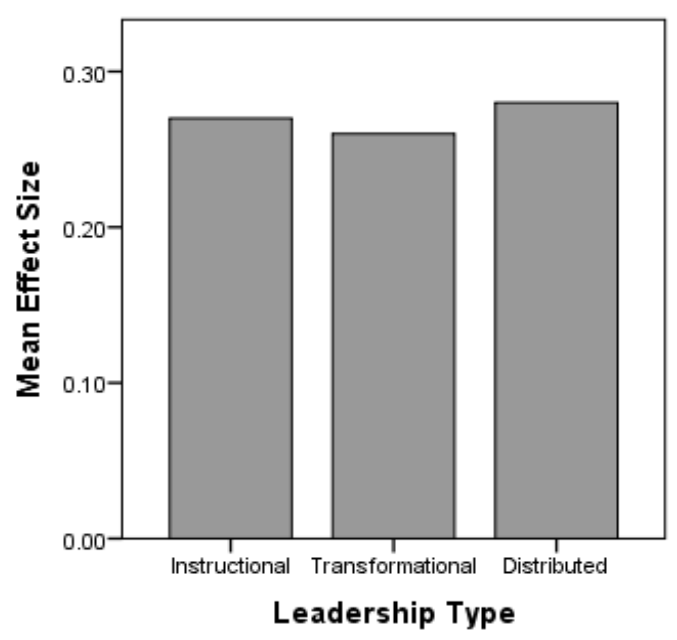

Figure 1. Effect of Leadership on Students' Academic Outcomes

The reported effects of different types of leadership found in the empirical literature notes to the inconsistent impact of leadership on students' academic achievement. First, six reported effect sizes correspond to instructional leadership with three ranging between -0.1 and +0.1 indicating a very weak effect while the remaining three indicate a moderate to strong impact on students' outcomes. Similarly, the effects of transformational leadership were found to be weak, between -0.2 to 0.2 , in three of the studies and stronger, above 0.3 in the remaining three. All four studies found for distributed leadership reported weak to moderate effects on students' academic outcomes.

Interestingly, few studies reported negative effect sizes of leadership on students' academic outcomes. Despite the small, practically insignificant results, the effect of leadership on students' outcomes is not always positive. Both instructional and transformational leadership types yielded negative effects while distributed leadership has generated positive effects in all of the four studies found. Those small to negative effects have reduced the impact, effect size, of leadership types on students' achievement.

Despite the similar effects of leadership types on students' academic outcomes, one needs to be careful when interpreting such results. First, the range of effects within instructional and transformational leadership have been found to be high. In few cases, the effects reached 0.81 and others they were negative. It seems that most studies that reported a stronger effect of leadership utilized an outcome measure of academic ability in language arts or reading rather than mathematics. Furthermore, studies that controlled for more variables reported lower effect sizes compared to those that only utilized leadership and fewer controls. 
The findings indicate that distributed leadership, a form of collectivist administration that incorporates all stakeholders at a school, was found to be a more effective form of leadership yielding better academic results for students. This finding is in line with earlier confirmations that more integrated forms of leadership are better for increasing the levels of academic performance at schools. In sum, the findings suggested that there is no practical difference among leadership types in their effects on students' academic outcomes. Further, more collectivist, integrated and shared types of leadership, distributed leadership, were found to have a stronger positive impact on students' academic achievement.

\section{Discussion}

This study analyzed the effects of three different types of leadership on students' academic outcomes. The findings above indicated that leaders' practices have a weak effect on students' academic achievement, in all types mean effect size estimates were below 0.30. Further, the results confirmed earlier findings suggesting that the closer leaders are to the schools' teaching, learning and students' academic side of things, the more positive impact leaders have on schools' academic performance. This is evident by the stronger effect of distributed leadership, which engages all school administrators in the teaching and learning process, on students' academic achievement.

Despite its valuable contributions to the existing scholarship linking educational leadership to students' achievement, this research suffers from a number of limitations. First, only 14 studies were included in the meta-analysis and 16 effect sizes were calculated. Of those, only 4 studies investigated the effect of distributed leadership on students' academic outcomes. This number of studies is less than previous syntheses since it was limited in its timeframe, 2006-2015 as well as type of analysis, correlational designs. Second, the research does not dissect academic outcomes into more categories such as Mathematica, reading or language arts abilities rather it takes all of those as a unified cattery of academic achievement measures.

The findings of this study confirms earlier meta-analyses that found weak to moderate effects of leadership types on students' outcomes. The findings confirm Robinson's et al, as well as Marzanos' and colleague's meta-analyses concluding that the effect of leadership on students' outcomes is moderate, around 0.40. The findings also support earlier confirmations that leadership has a small positive effect on academic achievement. Liethwood and Janzi (2012) review of unpublished literature on the effect of transformational leadership on students' academic outcomes found an average effect of 0.09 .

Excluding school, as well as non-academic outcomes confirms that the relationship between educational leadership and students' achievement is not as it is claimed in policy making and public circles. Leadership, however measured, concerns the relationship between leaders and followers. This entails the type of management straggles principals and other key school administrators use to administer the financial, human, structural and other related characteristics of their schools. The engagement of school administrators with students' 
learning in and outside of the classroom is limited. Nevertheless, when one considers distributed forms of leadership, school administrators are more engaged in everyday teaching and learning activities taking place at their institutions building a more positive impact on the academic achievements of their students.

The findings allude to the fact that successful leadership entails the active empowerment of all administrators within the school administration in order to achieve acceptable academic outcomes for students. Principals and key administrators generate a larger effect on students' academic performance when they interact with the teaching and learning processes. This model may be used to devise best leadership practices to be disseminated at schools and educational institutions.

The study uncovered few dark spots in the research agenda of leadership effects on students' outcomes. First, there is a dearth of cross-sectional research linking leadership to students' outcomes across countries. Second, the comprehensive search for studies to be included in the synthesis alluded to the paucity of investigations in the developing world. This calls for immediate attention to the role of leaders in determining students' outcones in the developing world. This is especially important given the significant effect of leaders on falling schools in light with the fact that many schools operating in the developing world are located on the bottom of the academic performance ladder.

\section{References}

Alia, C. O. (2015). The impact of principals' leadership behavior on academic achievement of students (Doctoral dissertation, TEXAS SOUTHERN UNIVERSITY).

Bass, B. M. (1999). Two decades of research and development in transformational leadership. European journal of work and organizational psychology, 8(1), 9-32. https://doi.org/10.1080/135943299398410

Bass, B. M., \& Riggio, R. E. (2006). Transformational leadership. Psychology Press.

Bell, L., Bolam, R., \& Cubillo, L. (2003). A systematic review of the impact of school headteachers and principals on student outcomes.

Brazer, S. D., \& Bauer, S. C. (2013). Preparing Instructional Leaders A Model. Educational Administration Quarterly, 49(4), 645-684. https://doi.org/10.1177/0013161X13478977

Chen, S. S. (2014). The effects of transformational leadership of principals on student academic achievement (Doctoral dissertation, California State University, Stanislaus).

Chin, J. M. C. (2007). Meta-analysis of transformational school leadership effects on school outcomes in Taiwan and the USA. Asia Pacific Education Review, 8(2), 166-177. https://doi.org/10.1007/BF03029253

Goddard, Y. L., Miller, R., Larsen, R., Goddard, R., Madsen, J., \& Schroeder, P. (2010). Connecting Principal Leadership, Teacher Collaboration, and Student Achievement. 
Online Submission.

Hardman, B. K. (2011). Teacher's perception of their principal's leadership style and the effects on student achievement in improving and non-improving schools (Doctoral dissertation, University of South Florida).

Harris, A. (2013). Distributed Leadership Friend or Foe?. Educational Management Administration \& Leadership, 41(5), 545-554. https://doi.org/10.1177/1741143213497635

Hedges, L. V., \& Olkin, I. (2014). Statistical methods for meta-analysis. Academic press.

Herndon, B. C. (2007). An analysis of the relationships between servant leadership, school culture, and student achievement (Doctoral dissertation, University of Missouri--Columbia).

Horng, E., \& Loeb, S. (2010). New thinking about instructional leadership. Phi Delta Kappan, 92(3), 66-69. https://doi.org/10.1177/003172171009200319

Karadağ, E., Bektaş, F., Çoğaltay, N., \& Yalçın, M. (2015). The effect of educational leadership on students' achievement: a meta-analysis study. Asia Pacific Education Review, 16(1), 79-93. https://doi.org/10.1007/s12564-015-9357-x

Kempster, S., Higgs, M., \& Wuerz, T. (2014). Pilots for change: exploring organisational change through distributed leadership. Leadership \& Organization Development Journal, 35(2), 152-167. https://doi.org/10.1108/LODJ-04-2012-0055

Ko, J. F. (2015). A Correlational Study of Early Childhood Transformational Leadership and Young English Language Learners Achievement. Northcentral University.

Lee, M., Walker, A., \& Ling Chui, Y. (2012). Contrasting effects of instructional leadership practices on student learning in a high accountability context. Journal of Educational Administration, 50(5), 586-611. https://doi.org/10.1108/09578231211249835

Leithwood, K., \& Mascall, B. (2008). Collective leadership effects on student achievement. Educational administration quarterly, 44(4), 529-561. https://doi.org/10.1177/0013161X08321221

Leithwood, K., \& Sun, J. (2012). The nature and effects of Transformational school leadership a meta-analytic review of unpublished research. Educational Administration Quarterly, 48(3), 387-423. https://doi.org/10.1177/0013161X11436268

Leithwood, K., Day, C., Sammons, P., Harris, A., \& Hopkins, D. (2006). Successful school leadership: What it is and how it influences pupil learning.

Leithwood, K., Seashore Louis, K., Anderson, S., \& Wahlstrom, K. (2004). Executive Summary: Review of Research: How Leadership Influences Student Learning.

Mark W.. Lipsey, \& Wilson, D. B. (2001). Practical meta-analysis (Vol. 49). Thousand Oaks, CA: Sage publications. 
Marzano, R. J., Waters, T., \& McNulty, B. A. (2005). School leadership that works: From research to results. ASCD.

Menon, M. E. (2015). Leadership theory and educational outcomes: the case of distributed and transformational leadership.

Neumerski, C. M. (2013). Rethinking Instructional Leadership, a Review What Do We Know About Principal, Teacher, and Coach Instructional Leadership, and Where Should We Go From Here?. Educational administration quarterly, 49(2), 310-347. https://doi.org/10.1177/0013161X12456700

Quinn, R. R. (2011). The Effect of Elementary Principals' Self-Perceived Instructional Leadership Behaviors on Reading and Math Student Achievement. ProQuest LLC. 789 East Eisenhower Parkway, PO Box 1346, Ann Arbor, MI 48106.

Robinson, V. M., Lloyd, C. A., \& Rowe, K. J. (2008). The impact of leadership on student outcomes: An analysis of the differential effects of leadership types. Educational administration quarterly, 44(5), 635 - 674. https://doi.org/10.1177/0013161X08321509

Seashore Louis, K., Dretzke, B., \& Wahlstrom, K. (2010). How does leadership affect student achievement? Results from a national US survey. School effectiveness and school improvement, 21(3), 315-336. https://doi.org/10.1080/09243453.2010.486586

Shatzer, R. H., Caldarella, P., Hallam, P. R., \& Brown, B. L. (2013). Comparing the effects of instructional and transformational leadership on student achievement Implications for practice. Educational Management Administration \& Leadership, 1741143213502192.

Spillane, J. P. (2012). Distributed leadership (Vol. 4). John Wiley \& Sons.

Supriadi, E., \& Yusof, H. A. R. B. M. (2015). Relationship between Instructional Leadership of Headmaster and Work Discipline and Work Motivation and Academic Achievement in Primary School at Special Areas of Central Jakarta. Journal of Education and Learning, 4(3), 123. https://doi.org/10.5539/jel.v4n3p123

Valentine, J. W., \& Prater, M. (2011). Instructional, transformational, and managerial leadership and student achievement: High school principals make a difference. NASSP Bulletin, 95(1), 5-30. https://doi.org/10.1177/0192636511404062

Waters, T., Marzano, R. J., \& McNulty, B. (2003). Balanced Leadership: What 30 Years of Research Tells Us about the Effect of Leadership on Student Achievement. A Working Paper.

Witziers, B., Bosker, R. J., \& Krüger, M. L. (2003). Educational leadership and student achievement: The elusive search for an association. Educational administration quarterly, 39(3), 398-425. https://doi.org/10.1177/0013161X03253411

Zepeda, S. J. (2013). Instructional leadership for school improvement. Routledge. 


\section{Copyright Disclaimer}

Copyright for this article is retained by the author(s), with first publication rights granted to the journal.

This is an open-access article distributed under the terms and conditions of the Creative Commons Attribution license (http://creativecommons.org/licenses/by/3.0/). 